\title{
Organisational politics on job satisfaction: An empirical study of police officials in a selected police service station
}

\begin{tabular}{|c|c|}
\hline \multicolumn{2}{|c|}{$\begin{array}{l}\text { Authors: } \\
\text { Wiza Munyeka }{ }^{1} \\
\text { Sam T. Setati² }\end{array}$} \\
\hline \multicolumn{2}{|c|}{$\begin{array}{l}\text { Affiliations: } \\
\text { 'Department of Human } \\
\text { Resource Management and } \\
\text { Labour Relations, Faculty of } \\
\text { Management Sciences, } \\
\text { University of Venda, } \\
\text { Thohoyandou, South Africa }\end{array}$} \\
\hline \multicolumn{2}{|c|}{$\begin{array}{l}{ }^{2} \text { Department of Business } \\
\text { Management, Faculty of } \\
\text { Management Sciences and } \\
\text { Law, University of Limpopo, } \\
\text { Polokwane, South Africa }\end{array}$} \\
\hline \multicolumn{2}{|c|}{$\begin{array}{l}\text { Corresponding author: } \\
\text { Wiza Munyeka, } \\
\text { masterwiza2000@yahoo.com }\end{array}$} \\
\hline \multicolumn{2}{|c|}{$\begin{array}{l}\text { Received: } 29 \text { Mar. } 2021 \\
\text { Accepted: } 17 \text { Sept. } 2021 \\
\text { Published: } 12 \text { Jan. } 2022\end{array}$} \\
\hline \multicolumn{2}{|c|}{$\begin{array}{l}\text { How to cite this article: } \\
\text { Munyeka, W. \& Setati, S.T., } \\
\text { 2022, 'Organisational politics } \\
\text { on job satisfaction: An } \\
\text { empirical study of police } \\
\text { officials in a selected police } \\
\text { service station', Africa's } \\
\text { Public Service Delivery } \\
\text { and Performance } \\
\text { Review 10(1), a552. } \\
\text { https://doi.org/10.4102/ } \\
\text { apsdpr.v10i1.552 }\end{array}$} \\
\hline \multicolumn{2}{|c|}{$\begin{array}{l}\text { Copyright: } \\
\text { (c) 2022. The Authors. } \\
\text { Licensee: AOSIS. This work } \\
\text { is licensed under the } \\
\text { Creative Commons } \\
\text { Attribution License. }\end{array}$} \\
\hline \multicolumn{2}{|l|}{ Read online: } \\
\hline 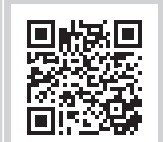 & $\begin{array}{l}\text { Scan this QR } \\
\text { code with your } \\
\text { smart phone or } \\
\text { mobile device } \\
\text { to read online. }\end{array}$ \\
\hline
\end{tabular}

Background: The phenomenon of organisational politics is widely recognised in organisations, and it can have a significant impact on job satisfaction. A negative organisational variable, organisational politics alters the organisational environment, culture and behaviour. The study of organisational politics is proliferating and is now a popular research topic. In terms of job satisfaction, this can be divided into two different categories: hygiene and motivation. The purpose of this study is to explore how organisational politics affect motivational and hygiene factors in relation to job satisfaction.

Aim: This study aimed to investigate the relationship between organisational politics and job satisfaction amongst police officials in a selected South African police service station in the Limpopo province.

Setting: An empirical investigation was undertaken using a sample of 114 police officers drawn using the random sampling technique.

Methods: A quantitative methodology, using self-administered surveys consisted of the Perception of Politics Scale (POPS) and Job Satisfaction Questionnaire (JSQ) was employed to collect data. The data were analysed using the Statistical Package for the Social Sciences (SPSS), version 24. Inferential statistics in the form of Pearson correlation analysis was used to test for relationships between the independent variable (organisational politics) and the dependant variable (job satisfaction).

Results: The findings of the study revealed that organisational politics has a significant negative relationship with job satisfaction.

Conclusion: It is recommended that police management should attempt to deal with perceptions of organisational politics and job satisfaction adequately.

Keywords: job satisfaction; Job Satisfaction Questionnaire (JSQ); organisational politics; Perception of Politics Scale (POPS); South African police services.

\section{Introduction}

Drive and foresight in leadership are essential prognosticators of values and norms in organisations, coupled with strategic direction, successful orientation, organisational dynamics and innovation (Masale 2020). The collection of all the expertise, capacity and knowledge of all the people working in any organisation is indisputably considered the most precious asset. It is essential to include all the people working to attain the most wanted goals (Ullah \& Ahmad 2018).

According to Raziq and Maulabakhsh (2015), organisations in the modern age face several challenges as a result of the complicated existence of the climate. One of the many challenges for a company is to satisfy its workers to deal with an ever-changing and developing world, achieve success and stay competitive.

\section{Authors Gull and Zaidi (2012) describe:}

$[O]$ rganisational politics as an activity that permits people to accomplish goals without proper channels. Whether political activities assist or harm the organisation depends on whether individuals' objectives are consistent with their purposes. (p. 156)

Gull and Zaidi (2012) state that there is no question that political viewpoints are a usual discernible reality in every single organisation. In addition, Gull and Zaidi (2012) highlight that organisational 
politics entails that employees have self-interests at heart, their behaviour is manifested as devious towards their work environment. The manifestation of these self-interests may be costly to other employees or maybe organisational goals as well. Gull and Zaidi (2012) further assert that job satisfaction is employees' feelings towards their job. Weaver et al. (2015) state that having a positive emotional state resulting from a person's appraisal of his or her job can be defined as job satisfaction.

Organisational politics has resulted in a strong effect on output. It interferes in businesses' usual processes like promotions, decision-making and rewards, which significantly affect productivity and performance on both an organisational and individual level (Rim, Yang \& Lee 2016). Besides, Budiasih et al. (2020) highlight that fairness and justice are unswervingly and substantially linked to political perceptions, which have more significant impact (both positive and negative) on personnel satisfaction but varies from person to person.

The current study was conducted to identify the relationship between organisational politics and job satisfaction amongst police officials in a selected South African Police Service (SAPS) station.

The Republic of South Africa (1996) Constitution clearly outlines under chapter 11 that the SAPS is tasked with law enforcement in South Africa. The SAPS is in charge of investigating crime and maintaining safety and security throughout the country (Muntingh \& Dereymaeker 2013). Functions include the following:

- police operationalised functions include patrolling

- crime investigation and

- traffic control (Ngugi et al. 2012).

In the Republic of Kenya 2009's report on National Task Force on Police Reforms, it is highlighted that the police officials's roles in most countries go further than the three listed as police functions and are linked to its objectives. The Police Reforms' National Task Force (the Republic of Kenya 2009) also affirms that police also perform duties such as:

- firefighting,

- prison duties,

- parking control,

- border and immigration control,

- prosecution,

- national security and

- intelligence functions and protection of very important persons (V.I.P.s).

Ercikti et al. (2011) accentuated the significance of exploring police job satisfaction and argued that negative attitudes towards work could negatively affect job performance in both the quantity and quality of services provided. If officers have a negative belief and attitude towards their job, they could intentionally or unintentionally express their stress towards the citizens they encounter.
Researchers have investigated the rapport between employees and their employing organisation for decades (Stinglhamber et al. 2015). They are aware of the importance of employees who are the organisation's driving force (Jordan, Miglič \& Marič 2016). Various research studies by Abdulla, Djebarni and Mellahi (2011), Bennett (1979), Chan and Doran (2009), Kuo (2015), Lu et al. (2015), Nalla and Kang (2012) and Nalla, Rydberg and Meško (2011) reveal that, in the last decade, it has also been observed that research has expanded to include job satisfaction amongst police personnel across different countries. Olasupo et al. (2019) assert that employees feel unsupported and cheated when they perceive their organisation's politics as unfavourable. The result is an unhealthy work life because employees may not be satisfied with their jobs. To better comprehend the rapport between organisational politics and job satisfaction, the current study explored this by applying analysis on 114 police officers at a selected SAPS station.

\section{Theoretical framework}

A widely used theory in job satisfaction research is Herzberg's Two-Factor Theory (1957), which explains the difference between motivational factors and hygiene factors. If challenging and engaging tasks are given to employees and they grow and demonstrate responsibility, Herzberg's Two-Factor Theory (1957) informs that employees will be motivated.

To be satisfied with one's workplace, there must be a certain amount of satisfaction. For example, police officers who perceive poor pay satisfaction coupled with high organisational politics tend to lose interest in their job, which tends to affect their work output. Knowing what role pay satisfaction and organisational politics play in the satisfaction of police officers will lead to improved efforts to improve psychological interventions.

Herzberg, Mausner and Snyderman developed the motivation-hygiene theory in 1959, which was heavily influenced by Maslow's hierarchy of needs (Jones 2011). According to Herzberg, work attitudes are influenced by two factors. The original Herzberg model in 1959 suggested that job satisfaction and dissatisfaction were related to distinct sets of factors, which made it impossible for job satisfaction and dissatisfaction to be measured side by side consistently (Herzberg et al. 1959; Stello 2011). To determine what causes employee dissatisfaction or satisfaction in the work environment, studies were conducted on job satisfaction. Two pilot studies, the first involving 13 working class people, the second involving 39 middle managers, led to further development and expansion of his theory (Herzberg et al. 1959). A key aspect of the two-factor theory is that it emphasises intrinsic and extrinsic factors, or factors of motivation and hygiene. Motivating factors correlate with intrinsic job characteristics, whilst hygiene factors correlate with extrinsic job characteristics. In this respect, motivation factors improve job satisfaction, whilst hygiene factors 
reduce job dissatisfaction. Alshmemri, Shahwan-Akl and Maude (2017) report that motivation factors improve job satisfaction and those associated with hygiene improve work satisfaction.

Therefore, understanding the perceptions of organisational politics will have implications for how psychological interventions can be organised to improve job satisfaction in the context of Herzberg's Two-Factor Theory (1957).

\section{Problem statement}

According to Jain and Ansari (2018), organisational politics impacts on almost every worker to a certain extent and this could become an unavoidable and substantial part of the whole organisation. Negative behaviour towards work and organisation could generally develop by employees who feel victimised by office politics, affecting their performances.

According to Chen (2018), the combination of a heavy workload and irregular work shifts in police work, as well as conflict and unpleasant and violent encounters with people, may cause stress and depression.

These work-related variables need to be dealt with by the police officers and the departments' challenges, including organisational injustice, bureaucracy and pressure from supervisors and peers. Furthermore, Chen (2018) asserts that, in contemporary policing, support from the communities that these police officers operate from is essential. The police performance and capacity are anchored on the support they receive from the communities, and this translates into the enjoyment of work as police services and their inclination to devoting themselves to their occupation.

It is in this regard that this study seeks to explore how organisational politics impacts on job satisfaction that influences the perceptions of police officers at a selected police station in the Limpopo province.

\section{Objectives of the study}

- The main objective of this study is to measure the perceptions of organisational politics and job satisfaction amongst police officials.

- To give recommendations to the management on leadership strategies that can be used to handle organisational politics in order to improve job satisfaction based on the research findings.

\section{Research hypothesis}

H 1: There is a negative relationship between organisational politics and job satisfaction amongst police officers.

\section{Literature review Organisational politics}

Organisational politics has had a strong impact on output because it inhibits businesses' usual processes such as:
- promotions,

- decision-making and

- rewards that severely affect productivity and performance on both an organisational and individual level (Saleem 2015).

Authors Lau et al. (2017) allude to the fact that fairness and justice are unswervingly and firmly linked with the politics of perceptions, which have a more substantial impact (both positive and negative) on personnel job satisfaction but is different amongst individuals. Not surprisingly, Bodla, Afza and Danish (2015) and Chinomona and Mofokeng (2016) noted that, over the past few years, organisational politics has become a noteworthy area of study of the dominant factors and ways organisations are run.

Politics is an inevitable fact of organisation life (Gupta 2011). Gupta (2011) argues that the covert and subject to differences in perception mostly characterises political behaviour in organisations. Gupta (2011) further states that a person's behaviour is influenced by the person's interpretations of the organisational climate, which is a result of organisational politics being a situational indicator.

Ferris and Treadway (2012) also aver that all organisations have politics inside because of different interests and ideas of the people. In addition, Atinc et al. (2010) state that politics can also be classified as self-interest, like:

- taking credit from other people's work,

- building consolidation,

- personal attacks on workers who compete for the same resources and

- make decisions based on favouritism.

Numerous authors like Allen et al. (1979), Ferris et al. (2002), Rosen et al. (2009), Ferris and Hochwarter (2011) and Ferris and Treadway (2012) have stated for more than 30 years that organisational politics has been the focus of significant research attention. Rosen et al. (2009:203) define organisational politics as 'activities that are illegitimate, self-serving, and often harmful to the organisation or its members'. Gull and Zaidi (2012:156) define 'organisational politics as an activity that permits people in organisations to accomplish goals without going through proper channels. Politics can either help or hurt an organization if it is aligned with its goals'.

\section{According to Gull and Zaidi (2012):}

$[T]$ here has been no doubt that political beliefs are observable in every organization. Therefore, organisational politics reflect devious behavior of employees towards their workplace only in the interest of self-interest. (p. 156)

The self-interests of some employees may be at the expense of others or of organisation goals.

According to Mintzberg (1983:172), organisation politics is social influence behaviour designed to displace legitimate 
power. In addition, a study from Ferris and Treadway (2012) suggests organisation politics is 'social influence behavior designed to maximise self-interest'. Vigoda (2000), however, contends that these definitions are not consistent with employees' general perceptions but carry a negative connotation.

People typically describe political behaviour at work in negative terms when asked about it. According to Vigoda (2000), employees perceive organisational politics primarily as self-serving policies that promote their interests. Actions of this nature are often considered discretionary and include:

- associated with manipulation

- defamation

- subversiveness and abuse of power and

- contrary to organisational goals and the interests of other individuals.

The behaviour of discrediting one's rival at work in an attempt to advance, withholding useful information to increase one's state of power over others, and doing favours for the boss to secure a pay raise is an example of political behaviour, according to Poon (2003:140). As a result, O'Connor and Morrison (2001:2) describe organisation politics as behaviours that occur on an informal basis within an organisation and involve intentional acts of influence when conflicting ways of achieving the goal might be necessary.

The ambiguity of a phenomenon does not render it relevant to either science or application. However, research findings suggest that political factors often influence behaviours within and amongst organisations. As Poon (2003:4) puts it, 'organisational politics entails social influence behaviours that are designed to maximize self-interest'. Poon (2003) further stated that organisational politics proposes that numerous factors affect perceptions of organisational politics. In general, the proposed precursors of perceptions of organisational politics have been categorised into personal factors such as:

- demographic factors

- personality characteristics

- attitudes, needs and values and

- situational factors at the job level, factors such as:

- job autonomy and job variety,

As well at the organisational level, factors such as:

- centralisation and formalisation.

Poon (2003) identifies those perceptions of organisational politics, which gave rise to effects such as psychological outcomes, such as job stress like attitudinal outcomes, job satisfaction and behavioural outcomes, for example, employee turnover. To this end, according to Poon (2003), factors such as control and understanding have been forwarded as remedies that can moderate the rapport between politics and its consequences. Goyal, Pokhrel and Karki (2014) are, however, of the notion that employees' perceptions about organisational politics impact employees' morale substantially. However, this influence's nature and degree may vary from job to job and between individuals. People having high morale will thus have high worksatisfaction and vice-versa.

A study conducted by Bodla, Danish and Nawaz (2012) aimed to investigate the mediating role of organisational politics between the employees' job characteristics and morale and concluded that job ambiguity, skill variety, feedback and affective commitment are negatively correlated with perceptions of organisational politics. This confirms an earlier study by Brandes, Dharwadkar and Dean (1999) who looked at the effect of supervisors' behaviours on subordinate organisational behaviour.

\section{Job satisfaction}

Sila and Širok (2018) assert that job satisfaction is an essential attitudinal variable to research because of its strategic importance for organisational functioning. Job satisfaction has a long-standing practice in organisational research (Nguyen \& Borteyrou 2016). There are numerous definitions of job satisfaction according to Gözükara and Çolako lu (2016) and Westover and Taylor (2010). Understanding job satisfaction is significant for both employees and managers, as it impacts employees' productivity (Keles 2015). Park et al. (2016) also report that comprehending job satisfaction is essential for knowing if employment contributes to an individual's overall quality of life.

McShane and Von Glinow (2010:108) define 'job satisfaction as a person's evaluation of his or her job and work context'. Wood and West (2015:92) add on to define job satisfaction as 'it refers to a person's general feelings about their job, and more specifically the extent to which they feel positive or negative about it'.

The employee enjoys his or her job when he or she has a sense of job satisfaction. Motivation, effectiveness, retention and performance of workers are all influenced by job satisfaction. As a result of one's job and job experiences, job satisfaction can be a pleasurable, positive state.

Hajdukova and Klementova (2015) state that employees' job satisfaction affects their performance and commitment, and according to Hauff, Richter and Tressin (2015), job satisfaction is a primary concept in organisational psychology, and research on its determinants and outcomes is significant for the development of appropriate human resources management practices.

The assessment of the employee's work conditions is reflected in the attitudes, which are the unit of job satisfaction measurement (Hajdukova \& Klementova 2015). Peng (2014) further concluded that job satisfaction is multifaceted by nature and these facets can be classified into two dimensions namely:

- Intrinsic satisfaction 
Chatzoglou et al. (2011) state that intrinsic satisfaction is more related to the content of one's job, such as:

- autonomy,

- a variety of skills,

- supervision and

- the degree of responsibility.

This, according to Chatzoglou et al. (2011), intrinsic sources of satisfaction comprise the qualitative attributes of a job.

- Extrinsic satisfaction

Chatzoglou et al. (2011) assert that extrinsic satisfaction is associated with one's work environment (working conditions), such as bonuses, tangible rewards, promotion opportunities, safety and working hours. It is noted, according to Valle and Witt (2001:4) that 'job satisfaction has been the most frequently examined outcome of politics'. Valle and Witt (2001:4) also highlight that the hostile effects of organisational politics are derived from its impact on the social contract, between the employee and the employer, which consists of both economic and social exchanges.

Valle and Witt (2001:4) found that 'organisational politics affects both the economic and social aspects of the employeremployee exchange, for example, network-based relationships formed to advance self-interests, common in highly political environments, compromise the quality of promotion decisions'.

Valle and Witt (2001:4) further reported that 'individuals reporting high levels of politics expressed lower levels of job satisfaction than did those perceiving low levels of organisational politics'. Menon and Thompson (2010:74) also point out that negatives such as envy, the distress one feels when wanting what others want, if left unchecked, can sabotage not only one's performance but also the overall company performance. This 'damages relationships, disrupt teams, and undermines organisational performance'.

Wang (2007:6) is of the idea that 'in the case of police job satisfaction, job redesign among other things has to consider how officers differently define their police role- as a crime fighter or as a community server'. Kumari (2011:53) says that by creating a positive workplace for their employees, they can increase their employees' job satisfaction. Wang (2007) also found that officers' job satisfaction is associated with leadership and co-workers' perceptions and relations with supervisors. Pay promotion and recognition had little connection to the officer's satisfaction with work. Wang (2007) indicates that confidence in the top leaders of the chain of command contributes to their department's satisfaction. However, intrinsic reward systems are also found associated with officer' job satisfaction. Similarly, according to Huang et al. (2016), the fulfilment of every prerequisite in the workplace by the organisation to its employees in terms of:

- salary, promotion,

- increments,

- quality environment and

- suitable style of leadership is said to create employee job satisfaction.

Budiasih et al. (2020), in a recent study, thus found that job satisfaction is an important part of the success of any organisation expecting to be enhanced during each stage of organisation success.

\section{Research methodology Design and approach}

A cross-sectional, quantitative descriptive design was used. This design was considered suitable because the objective of the study was predictive in nature and data were collected from participants at a single point in time. The sample was taken from police officers at a selected police station in the Limpopo province. Using a quantitative approach, Kumar (2019) asserts that a solid understanding of social behaviour can be measured with certainty. With the help of statistical methods, this research approach can analyse the relationships between variables (Bryman 2017).

\section{Sample size and sampling procedure}

Samples refer to groups of people selected from the study population to attend research studies (Fink 2019). In addition, Fink (2019) states that when the targeted population is too large, a sample is regularly used because the entire population may not be reachable for the study. Alvi (2016) defines the sampling procedure as 'the selection of a sample from a large group of individuals to participate in a study so that they represent the entire group from which they were selected'. Random samples $(n=114)$ were applied to all police officers at a selected police station in the Limpopo province of South Africa. All police officers identified were asked to complete the two questionnaires given to them.

\section{Justification for sample size}

Random sampling was used in the current study. The researchers visited the selected Limpopo police station during their pre-survey and found that there were 145 police officers in total. To ensure that the sample was representative of the whole population, an online Raosoft sample size calculator was utilised. Although 108 questionnaires were recommended as a minimum sample size, 135 questionnaires were distributed to accommodate those unusable and unanswered by the respondents. The Raosoft sample size calculator was used and a total of $N=145$ police officers and sample size of $n=108$ were deemed appropriate, calculated 
at $95 \%$ confidence level, and it is assumed that there will be $50 \%$ response rate as shown below. In Equation 1, $n$ is the sample size, $N$ is the population size and $e$ is the level of meticulousness.

$$
\begin{aligned}
& n=\frac{N}{1+N(e)^{2}} \\
& n=\frac{145}{1+145(0.05)^{2}} \\
& n=108
\end{aligned}
$$

To make sure that the appropriate sample was obtained, 135 police officials were randomly selected because it eliminated systematic bias by giving the total population of 145 police officers at the police station chosen an equal opportunity to be set in the sample. The reason why these settings were chosen was that a large number of police officers were found in this area and the settings were easily accessible to the researcher.

\section{Measurement}

The Perception of Politics Scale (POPS) and Job Satisfaction Questionnaire (JSQ) were used. These questionnaires consisted of general information, perceptions of organisational politics and job satisfaction. The general information consisted of general questions that included respondents' details like age, gender, highest qualifications, position (rank) in the organisation and the number of years served in the organisation. The first instrument, the POPS was developed by Kacmar and Ferris (1991) as cited in Fields to assess employees' perceptions that include politics in the organisation, supervisors' behaviour and actions of coworkers. The coefficient alpha value ranges from 0.87 to 0.91 (Cropanzano et al. 1997; Kacmar \& Baron 1999; Kacmar \& Ferris 1991 as cited in Fields). The second instrument used for this study was the JSQ developed by Wood, Chonko and Hunt (1986).

\section{Data collection}

All police officers $(n=114)$ were asked to complete the questionnaires, which were distributed amongst them. Two questionnaires were given to respondents, and each questionnaire consisted of three pages, and the respondents had to fill in their gender, groupings and rank categories or status.

The answers from the questionnaire ranged from strongly disagree (SD), moderately disagree (MD), slightly disagree (SLD), slightly agree (SLA), moderately agree (MA) and strongly agree (SA). There were 12 questions on perceptions of the organisational politics questionnaire and 18 questions on the job perceptions questionnaire. All respondents were given a week to complete the questionnaires. One hundred and fourteen questionnaires to 114 randomly selected police officers were distributed and returned.

\section{Procedure}

An introduction letter was obtained from the university where researchers were based and this introduced the researchers to the study settings. Thereafter, the researcher got permission from the Head of Departments or staff selected police station visited for the study. Respondents were thereafter educated on the purpose and objectives of the study. They were also informed that participation in the study was voluntary and that they were free to withdraw from the study whenever they felt uncomfortable to continue. The participants were also given assurance of confidentiality in their responses. The questionnaires were physically distributed to the participants with the help of two research assistants. A total of 135 questionnaires were distributed to the respondents at the close of work at a different point in time. However, only 114 questionnaires were found usable, which was still deemed adequate according to the Raosoft sample calculator. The retrieved questionnaires were subjected to Statistical Package for Social Science (SPSS) version 24 for appropriate statistical analysis.

\section{Validity and reliability of the instruments Perception of Politics Scale}

Organisational politics was measured using the POPS developed by Kacmar and Carlson (1997). Perceptions of organisational politics included general political behaviour items, go ahead and pay and promotion policies questions. For this study, general political behaviour consisted of six items, go ahead contained four, and pay and promotion contained two items. Responses that were obtained using 5-point Likert scale were measured from 1 (SA) to 5 (SD). There were 15 items on the scale. The scale ranges from 1-SA to 5-SD on a 5-point Likert scale. Sample items included 'People here try to build themselves up by tearing others down' and 'Promotions around here are not worth much because they are so political'. With a reliability coefficient of 0.93, the scale is highly reliable. Based on the study by Adebusuyi, Olasupo and Ldehen (2013), the internal consistency reliability estimate (Cronbach alpha) was 0.88 . According to the present study, the overall Cronbach coefficient for this scale was 0.86 .

\section{Job Satisfaction Questionnaire}

Wood et al. (1986) developed a measure for job satisfaction, and the contributing 14 items are rated on a Likert-scale from 1 (SD) to 5 (SA). Wood's JSQ validation contains four subscales that measure information satisfaction, variety satisfaction, closure satisfaction and pay satisfaction. When a member's total score is high, he or she is likely to be more satisfied with his or her job. Sample items in JSQ are as follows: I am satisfied with the information I receive from my superior about my job performance (satisfaction with information), I am satisfied with the variety of activities my job offers (satisfaction with variety), I am satisfied with the opportunities my job gives me to complete the tasks from beginning to end (satisfaction with closure) and I am satisfied with the pay I receive for my job (satisfaction with pay). 
Wood et al. (1986) found Cronbach's alpha for each subscale to be $0.93,0.88,0.80$ and 0.56 .

\section{Data analysis}

Data were analysed using the SPSS Version 24. The methods used were descriptive statistics and used to formulate frequency tables. Frequency tables were constructed to analyse the data collected in the sample, and an interval scale of measurement was utilised.

\section{Ethical considerations}

To conduct the study, the researchers obtained ethical approval from the university's Research Directorate. To carry out the study in the Limpopo province, South Africa, approval was sought from the selected police station. The researchers requested permission from the police station's management once they had received approval from the selected station. The researchers then explained the purpose of the research to the police staff once the researchers received permission. In considering ethical standards, the following were considered.

\section{Informed consent}

When human participants are involved in a research study, informed consent is fully required to conduct the study and inform the potential risks. Yip, Han and Sng (2016) define informed consent as the ethical requirement of such a study. Every police officer took part in the study after receiving informed consent from the researchers. During the research, the researcher made sure that respondents were aware that they could withdraw at any time if they felt their rights were violated or for any other reason without having to explain their motives to the researcher.

\section{Avoiding harm during the research}

An injury to a respondent's rights, safety and well-being that includes physical and mental factors is referred to as harm during the study (Cox 2019). The respondents in this study were not deceived or misled in any way, causing them mental discomfort. During the research, no participants experienced an injury because of any actions they took. To maintain respondents' autonomy, a process of informed consent was completed. As part of the research, the researchers considered the lasting impact of the researcher's actions.

\section{Confidentiality and anonymity}

Kumar (2019) states that privacy is of concern, along with the consent to view, share and use information. According to Farrugia (2019), keeping data confidential is fundamental to ethical research. It was explained how the informed consent process will maintain confidentiality.

Moreover, all data provided were strictly confidential and used for academic purposes only. Personal information and records are best protected by anonymity (Cox 2019).
In the questionnaires distributed to the respondents, the researchers ensured that no identifying information was revealed.

\section{Research findings Sample descriptive summary}

Demographical data were collected with the help of questions relating to employees' profiles.

Results showed that the population sample of employees was equally distributed between females and males. The police service institution employees were mostly above 21 years of age and almost equally distributed in the age groups of 20-35 years and 36-50 years as indicated by the questionnaire. Most of the subjects were matriculants, 25 (49.145656\%). The outcome of the survey is detailed in Table 1.

\section{Inferential statistics (Hypothesis testing)}

In testing the hypotheses of this study, correlational analysis was utilised. The correlation analysis helped establish the connection between the independent variables (age diversity, gender diversity, ethnic diversity and educational diversity) and the dependent variable (employee performance).

The Pearson's correlation coefficient was used to show the relationship's direction, strength and significance. According to Hair et al. (2007), the value that represents the Pearson correlation is called the $r$-value. The $r$-value ranges from -1.00 to +1.00 . A $+1.00 r$-value indicates a perfect positive linear relationship between the variables, and a $-1.00 r$-value demonstrates a perfect negative linear relationship between the variables (Hair et al. 2007). Given that the $r$-value is 0 , it means that there is no relationship between the variables.

Ferris and Treadway (2012) additionally assert that the $R$-value, together with the $p$-value, which indicates the relationship's statistical significance, can be utilised to provide a correlation analysis to show the direction, strength

TABLE 1: Demographic variables.

\begin{tabular}{llcc}
\hline Measures & Items & Frequency & Percent \\
\hline Age & 20-35 years & 57 & 50.000000 \\
& 36-50 years & 56 & 47.516457 \\
& 51-years and above & 1 & 2.6023404 \\
Highest Level of & Matriculation & 57 & 49.145656 \\
Education & Intermediate & 38 & 29.456461 \\
& Bachelors & 17 & 18.530769 \\
& Masters or above & 2 & 3.4768667 \\
Position & Constables & 55 & 57.692308 \\
& Superintendents & 35 & 25.130889 \\
Years with the & Other & 24 & 18.212343 \\
institution & $<1$ year & 25 & 21.222111 \\
& 1 to 2 years & 23 & 19.538462 \\
& 2 to 3 years & 17 & 15.384615 \\
& 3 to 5 years & 11 & 10.538462 \\
& 5 to 10 years & 17 & 15.384615 \\
& 10 years or more & 21 & 17.530769 \\
\hline
\end{tabular}


and importance of the relationship. The $p$-value can be based on a $99 \%$ confidence interval, meaning that if the $p$-value is lower than $0.01(p<0.01)$, it could be regarded as statistically significant and vice versa.

Given the above fact, the following hypothesis was tested, and the analysis was carried out in the following section.

In testing Hypothesis 1, which stated that there is a negative relationship between organisational politics and job satisfaction amongst police officers, Table 2 presents the relationship results.

A significant negative relationship was obtained between organisational politics and job satisfaction $(r=-0.309 *$, $\left.p=-0.124^{* *}\right)$. Thus, as reported by Ferris, Russ and Fandt (1989) and Ferris et al. (2002), the current study found evidence of a significant negative correlation between organisational politics and job satisfaction. This study's results have substantial implications in police officers' work job satisfaction resulting from organisational politics, such as delivering service to the public. Data generated by the study reveal that the sources of work-related stress amongst police officers were that, as Burks (2015:3) explains that 'older workers are more satisfied than younger workers with their jobs'.

This is true in the current study.

The hypothesis for the study was as follows:

H 1: There is a negative relationship between organisational politics and job satisfaction amongst police officers.

Previous examinations of the POP-job satisfaction relationship by Cropanzano et al. (1997), Ferris, HarrelCook and Dulebohn (2000), Harrell-Cook, Ferris and Dulebohn (2015), Kacmar et al. (1999) and Valle and Perrewe (2000) have usually found an inverse relationship. However, as mentioned above, the extensive range of correlations suggests that the accurate score correlation is far from settled and that this relationship's moderators may exist.

\section{Inferential statistics on the relationship between the perceptions of organisational politics related to general political behaviour, go ahead and pay and promotion policies and job satisfaction}

Table 3 shows the inferential statistics on the relationship between the perceptions of organisational politics related to general political behaviour, go ahead and pay and promotion policies and job satisfaction.

\begin{tabular}{llcc}
\multicolumn{4}{l}{ TABLE 2: Relationship between organisational politics and job satisfaction. } \\
\hline Variable & Test & Job satisfaction & Organisational politics \\
\hline Organisational & Pearson correlation & $-0.309^{*}$ & - \\
politics & Sig. (2-tailed) & - & $-0.124^{* *}$ \\
& $N$ & 114 & 114 \\
\hline
\end{tabular}

*, correlation is significant at the $p<0.05$ level (2-tailed).

$* *$, correlation is significant at the $p<0.01$ level (2-tailed).
The relationship between overall organisational politics and overall job satisfaction is significant. A significant negative relationship was obtained between organisational politics and job satisfaction $(r=-0.309 *$, $\left.p=-0.124^{* *}\right)$. More specifically, political behaviour $(-0.331)$ and go ahead $(-0.402)$ variables negatively correlate with overall job satisfaction. Pay and promotion (0.300) were, however, found to be positively correlated with job satisfaction. Of all variables, political behaviour is found to be dominant.

Herzberg's Two-Factor Theory (1957) examines factors that motivate and demotivate employees and impact their overall job satisfaction. Similarly, the negative outcome in this study is in line with Herzberg's Two-Factor Theory.

\section{Discussion}

The current study confirms that perceived organisational politics has a negative relationship with job satisfaction. Ferris et al. (1989) demonstrated that when employees engage in political activities, others' perceptions of their political nature may increase. Such perception may upsurge job anxiety because of a more uncertain or ambiguous environment fuelled by the increased political behaviour.

Uddin and Kabir (2015), Mahmud, Hasan and Ashifa (2014), as well as Reiner and Zhao (1999) believe that numerous studies, various demographic characteristics such as education, age, sex, income, occupation and race influence job satisfaction.

The results showed that perception of organisational politics associated with job attitudes could become severe. It affects job satisfaction in the SAPS at a selected police station. In this regard, policy changes pay/promotions, routine jobs caused dissatisfaction. There is a negative relationship, as expected, between perceptions of organisational politics and job satisfaction. This is consistent with McShane and Von Glinow (2010:109), who report that 'organisations can suffer serious consequences when employees experience high job dissatisfaction levels'.

McShane and Von Glinow (2010:109) report that 35 independent samples were included in the meta-analysis of the relationship between organisational politics and job satisfaction. The total number of individual participants was 12733 for an average sample size of 364. The mean uncorrected correlation was -0.40 , but after correcting statistical artefacts, the corrected correlation was -0.45 . These results indicate that an extensive inverse relationship exists between perceptions of organisational politics and job satisfaction. After corrections, the 95\% confidence interval ranged from -0.73 to -0.17 and hence did not include zero (an indication that the accurate score correlation is likely to be negative). Thus, as reported by Ferris et al. (1989) and (Ferris et al. 2002), they all found 
TABLE 3: Inferential statistics on the relationship between the perceptions of organisational politics related to general pollical behaviour, get ahead and pay and promotion policies and job satisfaction.

\begin{tabular}{|c|c|c|c|c|c|}
\hline Variable & Values & Job satisfaction & Political behaviour & Get ahead & Pay and Promotion \\
\hline \multirow[t]{11}{*}{ JOB SATISFACTION } & Pearson correlation & 1 & $-0.003 * *$ & $-0.402 * *$ & $0.300 * *$ \\
\hline & Sig (2-tailed) & & 0.000 & 0.000 & 0.001 \\
\hline & Sum of squares and cross-products & 10.567 & -13.191 & 10.880 & 10.135 \\
\hline & Covariance & -203 & -133 & -114 & 0.142 \\
\hline & $N$ & 114 & 114 & 114 & 114 \\
\hline & Bias & 0 & 0.008 & 0.002 & -0.008 \\
\hline & $\begin{array}{l}\text { Bootstrap } \dagger \\
\text { 95\% Confidence Interval (Lower) }\end{array}$ & 1 & -0.482 & -0.4114 & 0.100 \\
\hline & 95\% Confidence Interval (Upper) & 1 & -0.328 & -218 & 0.469 \\
\hline & Pearson correlation & $-331 * *$ & 1 & $-0.302 * *$ & $-0.342 * *$ \\
\hline & Sig (2-tailed) & 0.000 & & 0.000 & 0.000 \\
\hline & Sum of squares and cross-products & -0.13 .191 & 32.181 & 16.109 & -0.23 .101 \\
\hline \multirow{8}{*}{$\begin{array}{l}\text { POLITICAL } \\
\text { BEHAVIOUR }\end{array}$} & Covariance & -0.133 & 0.417 & 0.178 & -0.268 \\
\hline & Bias & 0.004 & 0 & -006 & 0.002 \\
\hline & Standard error & 0.009 & 0 & 0.102 & 0.073 \\
\hline & $\begin{array}{l}\text { Bootstrap } \dagger \\
\text { 95\% Confidence Interval (Lower) }\end{array}$ & -0.578 & 1 & -0.187 & -0.482 \\
\hline & 95\% Confidence Interval (Upper) & -0.328 & 1 & 0.564 & -0.267 \\
\hline & Pearson correlation & $-402 * *$ & $0.302 * *$ & 1 & $-0.204 * *$ \\
\hline & Sig (2-tailed) & 0.000 & 0.000 & & 0.002 \\
\hline & Sum of squares and cross-products & 10.880 & 16.109 & 25.118 & 15.410 \\
\hline \multirow[t]{7}{*}{ GET AHEAD } & Covariance & -0.113 & 0.178 & 0.381 & -0.168 \\
\hline & $N$ & 114 & 114 & 114 & 114 \\
\hline & Bias & -0.004 & 0.004 & 0 & 0.002 \\
\hline & Standard error & 0.008 & 0.104 & 0 & 0.112 \\
\hline & $\begin{array}{l}\text { Bootstrap } \dagger \\
95 \% \text { Confidence Interval (Lower) }\end{array}$ & -533 & 0.187 & 1 & -518 \\
\hline & 95\% Confidence Interval (Upper) & -208 & 0.564 & 1 & -0.518 \\
\hline & Sum of squares and cross-products & 10.135 & -23.101 & -15.410 & 50.781 \\
\hline \multirow{6}{*}{$\begin{array}{l}\text { PAY AND } \\
\text { PROMOTION }\end{array}$} & Covariance & 0.142 & -0.268 & 0.170 & 0.667 \\
\hline & $N$ & 114 & 114 & 114 & 114 \\
\hline & Bias & 0.004 & 0.006 & 0.002 & 0 \\
\hline & Standard error & 0.088 & 0.096 & 0.107 & 0 \\
\hline & $\begin{array}{l}\text { Bootstrap } \dagger \\
95 \% \text { Confidence Interval (Lower) }\end{array}$ & 0.100 & -0.578 & -0.518 & 1 \\
\hline & 95\% Confidence Interval (Upper) & 0.489 & -0.267 & -0.78 & 1 \\
\hline
\end{tabular}

$\uparrow$, Unless otherwise noted, bootstrap results are based on 1000 bootstrap samples.

*, correlation is significant at the $p<0.05$ level (2-tailed).

**, correlation is significant at the $p<0.01$ level (2-tailed).

evidence of a significant negative correlation between POP and job satisfaction. In addition, a study conducted by Ram and Prabhakar (2010) provides proof of 11 different studies that agree that there is a relationship between organisational politics and job satisfaction. In other studies, researchers obtained different results concerning the association of job characteristics with police job satisfaction. An Indian study conducted by Lambert et al. (2015) found job variety rather than job autonomy to be a significant predictor of job satisfaction. In both Johnson's (2012) and Miller, Mire and Kim's (2009) studies, however, job autonomy exerted the most substantial effect in multivariate models.

The correlation of job variety with job satisfaction was not statistically significant. It must be kept in mind that the results were obtained from a sample of 114 police officials in the selected police station where the two questionnaire instruments were distributed.

\section{Conclusions}

In the study, it was found that negative organisational politics negatively impacted job satisfaction, which means low job satisfaction for employees who experienced negative organisational politics. A conclusion of the study is that there is a joint and independent relationship between promotion and pay satisfaction amongst officers in police departments.

This current study confirms that the variable organisational politics has a negative relationship with the variable job satisfaction. All organisational politics variables except for pay and promotion are negatively correlated leading to a 
conclusion that fair pay and promotion increases satisfaction. This is in line with earlier studies by Fields and Blum (1997), McFarlin and Rice (1992) and Pond and Geyer (1991).

This study's main objective was to measure the perceptions of organisational politics and job satisfaction amongst police officials, and the result findings showed a negative relationship between organisational politics and job satisfaction. Given this, if police officers learn to manage the negative aspects of organisational politics such as jealousy, behaviours to discredit each other and others will lead to job satisfaction and less stress because, as it is, the police work is a stressful job.

Ferris et al. (1989), as cited in the study by Poon (2003), mention that an increase in perceived organisational politics adversely leads to a decrease in job satisfaction. Poon (2003) explains that a reason for this adverse association is that decisions such as resource allocation decisions are governed by political agendas and are typically expressed as unfair conduct. Furthermore, conclusions are drawn to the fact that if employees perceive decision-making to be unjust and political, it will inevitably lead to employee dissatisfaction and unhappiness.

Curtis (2003) raises an interesting point by stating that organisations will be subject to diminished job satisfaction if competent individuals demonstrate feelings that their job performance and appraisals are solely based on their proficiency and ability to act politically rather than achieve good work. He concludes by adding that employees will become politically minded, resulting in feelings of dissatisfaction and lack of job commitment.

\section{Recommendations}

More research studies are needed to be performed about the perceptions of organisational politics and job satisfaction in the SAPS. Cross-sectional and longitudinal studies prove valuable in explaining the development of perceptions of organisational politics and job satisfaction in the SAPS.

In consideration of perceptions of organisational politics as a cause of job satisfaction, aspects of police officers' tasks such as policy changes, pay/promotions, supervisors and routine jobs should be targets for intervention and improvements. Henceforth, the police management should attend to deal with perceptions of organisational politics and job satisfaction adequately.

More frequent coaching, mentoring and counselling of a subordinate, especially constables, should aid individuals to develop an improved comprehension of the supervisor's priorities and help refine what is expected of the employees if they are to be successful. Organisations that consistently switch employees to different supervisors risk having subordinates who generally know the formal job demands but may be unaware of the subtleties that will enable them to survive in that political environment.
As the employee develops an understanding of the situation through experience, politics would be less ambiguous, less stressful and less likely to choose to stay away from the workplace.

In addition to the usual job instruction and feedback, employees could benefit from coaching and guidance on their workplace's political implications. Mentors often provide that a sort of assistance to those they choose to guide, but this study suggests that all neophytes may benefit from political coaching in a new workplace.

A future study with a larger population is recommended, which may help to derive more accurate results. It is highly suggested that there be decisive intervention from the Department of Police to introduce organisational politics workshops on policy and practices.

\section{Theoretical implications}

Theoretically, the findings of this study lend support to Herzberg's Two-Factor Theory (1957). In terms of support, this study supported that pay satisfaction and promotion as well as perceived organisational politics play a major role in the improvement of job satisfaction of police officers. According to the authors of this study, Herzberg's Two Factor Theory (1957) has not been applied to job satisfaction and organisation politics in a developing country before this study.

\section{Practical implications}

The practical implications of this study are firstly to assist on issues of absenteeism and other forms of withdrawal from the workplace, supervisors should acknowledge that organisational politics exist and aid their subordinates in ways that could help them overcome the stress and discomfort as well as uncertainty that comes with their jobs. Secondly, it is also essential for supervisors to facilitate the adoption of good political conduct in the workplace, improving job satisfaction and reducing the likelihood of dysfunctional political behaviour detrimental to the workplace and employees. Thirdly, in the police profession, the issues that promote stress and conflict in the work environment are complicated. Developing knowledge about how people can cope with stressors such as organisational politics facilitates organisations and employees to function more efficiently. Lastly, continued understanding of the dynamics of how organisational politics affects organisations is needed.

In conclusion, the concepts were presented, and the implications were discussed to provide insight into the work nature of police officers' organisational, political behaviour concerning job satisfaction. The article highlights the negative relationship between organisational politics and job satisfaction. The study's findings show that management should focus on employees' job satisfaction to reduce their engagement in organisational politics at the selected police services station. 


\section{Acknowledgements} Competing interests

The authors declare that they have no financial or personal relationships that may have inappropriately influenced them in writing this article.

\section{Authors' contributions}

Both W.M. and S.T.S. contributed equally to this work.

\section{Funding information}

This research received no specific grant from any funding agency in the public, commercial or not-for-profit sectors.

\section{Data availability}

Data sharing is not applicable to this article as no new data were created or analysed in this study.

\section{Disclaimer}

The views and opinions expressed in this article are those of the authors and do not necessarily reflect the official policy or position of any affiliated agency of the authors.

\section{References}

Abdulla, J., Djebarni, R. \& Mellahi, K., 2011, 'Determinants of job satisfaction in the UAE: A case study of the Dubai police', Personnel Review 40(1), 126-146. https://doi.org/10.1108/00483481111095555

Adebusuyi, A.S., Olasupo, M.O. \& Idehen, E.E., 2013, 'Analysis of the perception of organizational politics by employees of Obafemi Awolowo University, Ile-Ife, Nigeria', Bangladesh e-Journal of Sociology 10(1), 51-58.

Alshmemri, M., Shahwan-Akl, L. \& Maude, P., 2017, 'Herzberg's Two-Factor Theory', Life Sci. J. 14, 12-16.

Allen, R., Madison, D., Porter, L., Renwick, P. \& Mayes, B., 1979, 'Organisational politics: Tactics and characteristics of its actors', California Management Review 22(1), 77-83. https://doi.org/10.2307/41164852

Alvi, M.H. 2016, A manual for selecting sampling techniques in research, University of Karachi, Iqra University, Pakistan.

Atinc, G., Darrat, M., Fuller, B. \& Parker, B., 2010, 'Perceptions of organisational politics: A meta- analysis of theoretical antecedents', Journal of Managerial Issues 40, 126-146.

Bennett, R., 1979, 'Job satisfaction among police constables: A comparative study in three developing nations', Justice Quarterly 14(2), 295-323. https://doi. org/10.1080/07418829700093341

Bodla, M.A., Afza, T. \& Danish, R.Q., 2015, 'Perceived organisational politics and employee morale: Mediating role of social exchange perceptions in Pakistan omployee morale: Mediating role of social exchange perceptions in Pakistani

Bodla, M., Danish, R. \& Nawaz, M., 2012, 'Mediating role of perceived organisational politics in relating job characteristics to morale', African Journal of Business Management 6(15), 5185-5192. https://doi.org/10.5897/AJBM11.1246

Brandes, P., Dharwadkar, R. \& Dean, J.W., 1999, 'Does organisational cynicism matter? Employee and supervisor perspectives on work outcomes', Paper presented at the 36th Annual Meeting of the Eastern Academy of Management, Philadelphia PA pp. 1-34.

Bryman, A., 2017, 'Quantitative and qualitative research: Further reflections on their integration', in J. Brannen (ed.), Mixing methods: Qualitative and quantitative research, p. 5778, Routledge, New York, NY.

Budiasih, Y., Hartanto, C.F.B., Ha, T.M., Nguyen, P.T. \& Usanti, T.P., 2020, 'The mediating impact of perceived organisational politics on the relationship between leadership styles and job satisfaction', International Journal of Innovation, Creativity and Change 10(11), 478-495.

Burks, F., 2015, What is the relationship between job satisfaction and age?, viewed 18 March 2017, from http://smallbusiness.chron.com/relationship-between-jobsatisfaction-age-12618.html.

Chan, J. \& Doran, S., 2009, 'Staying in the job: Job satisfaction among mid-caree police officers', Policing 3(1), 66-77. https://doi.org/10.1093/police/pan078

Chang, C.-H., Rosen, C.C. \& Levy, P., 2009, 'The relationship between perceptions of organisational politics and employee attitudes, strain, and behaviour: A metaanalytic examination', Academy of Management Journal 52(4), 779-801. https:// doi.org/10.5465/amj.2009.43670894
Chatzoglou, P., Vraimaki, E., Komsiou, E., Polychrou, E. \& Diamantidis, A., 2011, 'Factors affecting accountants' job satisfaction and turnover intentions: A structural equation model', in Factors affecting accountants' job satisfaction and structural equation model, in Factors affecting accountants job satisfaction and turnover intentions: A structural equation model, Thassos Island, viewed 18
March 2017, from http://www.icesal.org/2011\%20PROCEEDINGS/docs/P7.pdf.

Chen, Z., 2018, 'Job satisfaction among frontline police officers in China: The role of demographic, work-related, organisational and social factors', Psychology, Crime \& Law 24(9), 895-914. https://doi.org/10.1080/1068316X.2018.1442835

Chinomona, E. \& Mofokeng, T.M., 2016, 'Impact of organisational politics on job dissatisfaction and turnover intention: An application of social exchange theory on employees working in Zimbabwean small and medium enterprises (SMEs) Journal of Applied Business Research 32(3), 857-870. https://doi.org/10.19030/ jabr.v32i3.9661

Cox, K.A., 2019, Research design and methods: An applied guide for the scholar practitioner, in G.J. Burkholder, K.A. Cox, L.M. Crawford \& J.H. Hitchcock (eds.) p. 199, Sage Publications.

Cropanzano, R., Howes, J., Grandey, A. \& Toth, P., 1997, 'The relationship of organisational politics and support to work behaviours, attitudes, and stress', Journal of Organisational Behaviour 18(2), 159-180. https://doi.org/10.1002/ (SICI)1099-1379(199703)18:2\%3C159::AID-JOB795\%3E3.0.CO;2-D

Curtis, S., 2003, 'Lies, damned lies and organisational politics', Industrial and Commercial Training 35(7), 293-297. https://doi.org/10.1108/00197850310501703

Ercikti, S., Vito, G., Walsh, W. \& Higgins, G., 2011, 'Major determinants of job satisfaction among police managers', The Southwest Journal of Criminal Justice 8(1).

Farrugia, L., 2019, 'WASP (write a scientific paper): The ongoing process of ethical decision-making in qualitative research: Ethical principles and their application to the research process', Early Human Development, 133, 48-51.

Ferris, G., Adams, G., Kolodinsky, R., Hochwarter, W. \& Ammeter, A., 2002, Perceptions of organisational politics: Theory and research directions, vol. 1, pp. 179-254, in F. Yammarino \& F. Dansereau (eds.), JAI Press, Greenwich, CT.

Ferris, G.R., Harrell-Cook, G. \& Dulebohn, J., 2000, 'Organizational politics: The nature of the relationship between politics perceptions and political behavior', in S.B. Bacharach \& E.J. Lawler (eds.), Research in the sociology of organizations, pp. 89-130, JAI Press, Greenwich, CT.

Ferris, G. \& Hochwarter, W., 2011, Organisational politics, in S. Zedeck, H. Aguinis, W. Cascio, M. Gelfand, K. Leong, S. Parker, et al. (eds.), Vol. 3, American Psychological Association, Washington, DC.

Ferris, G., Russ, G. \& Fandt, P., 1989, 'Politics in organisations', in Giacalone \& P. Rosenfeld (eds.), Hillside: impression management in the organisation, pp. 125-139, Erlbaum, Hillsdale, NJ.

Ferris, G. \& Treadway, D., 2012, Politics in organisations: History, construct specification and research directions, in G.R. Ferris \& D.C. Treadway (eds.), Routledge, New York, NY.

Fields, D. \& Blum, T., 1997, 'Employee satisfaction in work groups with different gender composition', Journal of Organisational Behaviour 18(2), 181-196. https://do org/10.1002/(SICI)1099-1379(199703)18:2\%3C181::AID-JOB799\%3E3.0.CO;2-M

Fink, A., 2019, Conducting research literature reviews: From the Internet to paper, Sage, London.

Gotsis, N. \& Kortezi, Z., 2010, 'Ethical considerations in organisational politics: Expanding the perspective', Journal of Business Ethics 93, 497-517. https://doi. org/10.1007/s10551-009-0241-7

Gözükara, I. \& Çolakoğlu, N., 2016, 'The mediating effect of work family conflict on the relationship between job autonomy and job satisfaction', Procedia-Social and Behavioural Sciences 229, 253-266. https://doi.org/10.1016/j.sbspro.2016.07.136

Gull, S. \& Zaidi, A., 2012, 'Impact of organisational politics on employees' job satisfaction in the health sector of Lahore Pakistan', Interdisciplinary Journal of Contemporary Research in Business 4, 156-170.

Gupta, B., 2011, 'Employees' knowledge sharing behaviour and work engagement: The role of organisational politics', International Journal of Business Excellence 4(2). https://doi.org/10.1504/IJBEX.2011.038786

Hair, J., Money, A., Samouel, P. \& Page, M., 2007, Research methods for business, John Wiley Sons, West Sussex.

Hajdukova, A. \& Klementova, J., 2015, 'The job satisfaction as a regulator of the working behaviour', Procedia-Social and Behavioural Sciences 190, 471-476. https://doi.org/10.1016/j.sbspro.2015.05.028

Harrell-Cook, G., Ferris, G. \& Dulebohn, J., 2015, 'Political behaviours as moderators of the perceptions of organisational politics - Work outcomes relationships', Journa of Organisational Behaviour 20, 1093-1105. https://doi.org/10.1002/(SICI)1099 1379(199912)20:7<1093::AID-JOB945>3.0.CO;2-\%23

Hauff, S., Richter, N. \& Tressin, T., 2015, 'Situational job characteristics and job satisfaction: The moderating role of national culture', International Business Review 24(4), 710-723. https://doi.org/10.1016/j.ibusrev.2015.01.003

Herzberg, F., 1957, The Two-Factor Theory, Psychological Service of Pittsburg, Pittsburg.

Herzberg, F., Mausner, B. \& Snydermann, B., 1959, The motivation to work, Wiley, New York, NY.

Huang, Y.-H., Lee, J., McFadden, A.C., Murphy, L.A., Robertson, M.M., Cheung, J.H et al., 2016, 'Beyond safety outcomes: An investigation of the impact of safety climate on job satisfaction, employee engagement and turnover using social exchange theory as the theoretical framework', Applied Ergonomics 55, 248-257. https://doi.org/10.1016/j.apergo.2015.10.007

Jain, L. \& Ansari, A.A., 2018, 'Effect of perception for organisational politics on employee engagement with personality traits as moderating factors', The South East Asian Journal of Management 12(1), 85-104. https://doi.org/10.21002/seam.v12i1.9396

Johnson, R.R., 2012, 'Police officer job satisfaction: A multidimensional analysis', Police Quarterly 15(2), 157-176. https://doi.org/10.1177/1098611112442809 
Jones, T.L., 2011, 'Effects of motivating and hygiene factors on job satisfaction among school nurses', PhD thesis, Walden University, Minneapolis, MN.

Jordan, G., Miglič, G. \& Marič, M., 2016, 'Comparison of organisational climate in the regional unit of the National Institute of Public Health before and after reorganisation', Mednarodna Revija Za Javno Upravo/International Public Administration Review 14(4). https://doi.org/10.17573/ipar.2016.4.04

Kacmar, K. \& Baron, R., 1999, Organisational politics: The state of the field, links to related processes, and an agenda for future research, in G.R. Ferris (ed.), JAI Press, Greenwich, CT.

Kacmar, K., Bozeman, D., Carlson, D. \& Anthony, W., 1999, 'An examination of the perceptions of organisational politics model: Replication and extension', Human Relations 52(3), 383-416. https://doi.org/10.1177/001872679905200305

Kacmar, K. \& Ferris, G., 1991, 'The perceptions of Organisational Politics Scale (POPS): Development and construct validation in taking measure of work' Educational and Psychological Measurement 51(1), 193-205. https://doi. org/10.1177/0013164491511019

Keles, H., 2015, 'The relationship between learned resourcefulness and job satisfaction: A research on staff of higher education in Turkey', Procedia-Social and Behavioural Sciences 177, 132-135. https://doi.org/10.1016/j.sbspro.2015.02.362

Kumar, R., 2019, Research methodology: A step-by-step guide for beginners, Sage, London.

Kumari, N., 2011, 'A live study of employee satisfaction and growth analysis: Tata steel', European Journal of Business and Management 3(10), 53-63.

Kuo, S., 2015, 'Occupational stress, job satisfaction, and affective commitment to policing among Taiwanese police officers', Police Quarterly 18(1), 27-54. https:// doi.org/10.1177/1098611114559039

Lambert, E.G., Qureshi, H., Hogan, N.L., Klahm, C., Smith, B. \& Frank, J., 2015, 'The association of job variables with job involvement, job satisfaction, and organisation commitment among Indian police officers', International Criminal Justice Review 25(2), 194-213. https://doi.org/10.1177/1057567715580985

Lau, P.Y.Y., Tong, J.L.T., Lien, B.Y.-H., Hsu, Y.-C. \& Chong, C.L., 2017, 'Ethical work climate, employee commitment and proactive customer service performance: Test of the mediating effects of organisational politics', Journal of Retailing and Consumer Services 35, 20-26.

Lu, L., Liu, L., Sui, G. \& Wang, L., 2015, 'The associations of job stress and organisational identification with job satisfaction among Chinese police officers: The mediating role of psychological capital', International Journal of Environmental Research and Public Health 12(12), 15088-15099. https://doi org/10.3390/ijerph121214973

Mahmud, M., Hasan, M. \& Ashifa, S., 2014, 'Determinants of job satisfaction: A comparative study in the banking sector of Bangladesh', International Journal of Economics and Empirical Research 2, 22-28.

Masale, R., 2020, 'Exploring the antecedents and consequences of a talent culture for government institutions in Botswana', Unpublished doctoral thesis, Department of Industrial Psychology, Mmabatho.

McFarlin, D. \& Rice, R., 1992, 'The role of facet importance as a moderator in job satisfaction processes', Journal of Organisational Behaviour 13(1), 41-54. https:// doi.org/10.1002/job.4030130105

McShane, S. \& Von Glinow, M., 2010, Organisational behaviour, 5th edn., McGraw-Hill Irwin, Boston, MA.

Menon, T. \& Thompson, L., 2010, 'Envy at work', Harvard Business Review 88(4), 749

Miller, H.A., Mire, S. \& Kim, B., 2009, 'Predictors of job satisfaction among police officers: Does personality matter?', Journal of Criminal Justice 37(5), 419-426. https://doi.org/10.1016/j.jcrimjus.2009.07.001

Mintzberg, H., 1983, Power in and around organisations, Prentice-Hall, Englewood Cliffs, NJ.

Muntingh, L. \& Dereymaeker, G., 2013, Understanding impunity in the South African law enforcement agencies, Civil Society Prison Reform Initiative (CSPRI)', Research Report, Bellville.

Nalla, M.K. \& Kang, W., 2012, 'Organisational climate, perceived citizen support, and job satisfaction of police officers: Findings from the post-grand reform era in s11417-012-9127-1

Nalla, M.K., Rydberg, J. \& Meško, G., 2011, ‘Organisational factors, environmental climate, and job satisfaction among police in Slovenia', European Journal of Criminology 8(2), 144-156. https://doi.org/10.1177/1477370810395317

Ngugi, J., Ngugi, P., Were, S. \& Titany, L., 2012, 'The factors influencing service delivery in the national police service: A case of the Kenya police in Nairobi County' Journal of Research in International Business and Management 2(11), 285-291.

Nguyen, N. \& Borteyrou, X., 2016, 'Core self-evaluations as a mediator of the relationship between person-environment fit and job satisfaction among laboratory technicians', Personality and Individual Differences 99, 89-93. https:// doi.org/10.1016/j.paid.2016.04.079

O'Connor, W.E. \& Morrison, T.G., 2001, 'A comparison of situational and dispositional predictors of perceptions of organisational politics', The Journal of Psychology 135(3), 301-312. https://doi.org/10.1080/00223980109603700

Olasupo, M.O., Idemudia, E.S., Arowosegbe, G.S. \& Fagbenro, D.A., 2019, 'Pay satisfaction and organisation politics as predictors of quality of work life among government employees', European Review of Applied Sociology 12(18), 32-42. government employees', European Review
https://doi.org/10.1515/eras-2019-0003

Park, Y., Seo, D., Park, J., Bettini, E. \& Smith, J., 2016, 'Predictors of job satisfaction among individuals with disabilities: An analysis of South Korea's National Survey of employment for the disabled', Research in Developmental Disabilities 53-54, 198-212. https://doi.org/10.1016/j.ridd.2016.02.009
Peng, Y.-P., 2014, 'Job satisfaction and job performance of university librarians: A disaggregated examination', Library and Information Science Research 1(36), 74-82. https://doi.org/10.1016/j.lisr.2013.02.006

Pond, S.B.I. \& Geyer, P., 1991, 'Differences in the relation between job satisfaction and perceived work alternatives among older and younger blue-collar workers', Journal of Vocational Behaviour 39(2), 251-262. https://doi.org/10.1016/00018791(91)90012-B

Poon, J.M.L., 2003, 'Situational antecedents and outcomes of organisational politics perceptions', Journal of Managerial Psychology 18(2), 138-155. https://doi. org/10.1108/02683940310465036

Ram, P. \& Prabhakar, G., 2010, 'Leadership styles and perceived organisational politics as predictors of work-related outcomes', European Journal of Social Sciences 15(1), 40-55.

Raziq, A. \& Maulabakhsh, R., 2015, 'Impact of working environment on job satisfaction', Procedia Economics and Finance 23, 717-725. https://doi. org/10.1016/S2212-5671(15)00524-9

Reiner, M.D. \& Zhao, J., 1999, 'The determinants of job satisfaction among United States Air Force Security Police: A test of rival theoretical predictive models', Review of Public Personnel Administration 19(3), 5-18. https://doi org/10.1177/0734371X9901900301

Republic of Kenya, 2009, National task force on police reforms, Government Printers, Nairobi.

Republic of South Africa, 1966, Labour Relations Amendment Act 2012, Government Printers, Pretoria.

Republic of South Africa, 1996, Constitution of the Republic of South Africa, Government Printers, Pretoria.

Rim, H., Yang, S.U. \& Lee, J., 2016, 'Strategic partnerships with non-profits in corporate social responsibility (CSR): The mediating role of perceived altruism and organizational identification', Journal of Business Research 69(9), 3213-3219.

Rosen, C.C., Chang, C.-H., Johnson, R.E. \& Levy, P.E., 2009, 'Perceptions of the organisational context and psychological contract breach: Assessing competing perspectives', Organisational Behaviour and Human Decision Processes 108(2) 202-217. https://doi.org/10.1016/j.obhdp.2008.07.003

Saleem, H., 2015, 'The impact of leadership styles on job satisfaction and mediating role of perceived organisational politics', Procedia-Social and Behavioural Sciences 172, 563-569. https://doi.org/10.1016/j.sbspro.2015.01.403

Sila, E. \& Širok, K., 2018, 'The importance of employee satisfaction: A case study of a transportation and logistics service company', Management 13(2), 111-136. https://doi.org/10.26493/1854-4231.13.111-136

Stello, C.M., 2011, 'Herzberg's two-factor theory of job satisfaction: An integrative literature review', In Unpublished paper presented at The 2011 Student Research Conference: Exploring Opportunities in Research, Policy, and Practice, University of Minnesota Department of Organizational Leadership, Policy and Development, Minneapolis, MN.

Stinglhamber, M., Marique, G., Caesens, G., Desmette, D., Hansez, I., Hanin, D. et al., 2015, Employees' organisational identification and affective organisational commitment: An integrative approach, viewed 26 April 2018, from http:// journals.plos.org/plosone/article?id=10.1371/journal. pone.0123955.

Uddin, M. \& Kabir, M., 2015, 'Satisfaction towards banking profession: A comparative study on male and female executives', IIUC STUDIES 12(2015), 127-138. https:// doi.org/10.3329/iiucs.v12i0.30586

Ullah, R. \& Ahmad, S.Z., 2018, 'The effect of organisation politics on job stress: Mediating role of job satisfaction', Electronic Journal of Business Ethics and Organization Studies 23(2).

Valle, M. \& Perrewe, P.L., 2000, 'Do politics perceptions relate to political behaviours? Tests of an implicit assumption and expanded model', Human Relations 53(3), 359-386. https://doi.org/10.1177/0018726700533004

Valle, M. \& Witt, L.A., 2001, 'The moderating effect of teamwork perceptions on the organisational politics-job satisfaction relationship', The Journal of Socia Psychology 141(3), 379-388. https://doi.org/10.1080/00224540109600559

Vigoda, E., 2000, 'Organisational politics, job attitudes, and work outcomes: Exploration and implications for the public sector', Journal of Vocational Behaviour 57(3), 326-347. https://doi.org/10.1006/jvbe.1999.1742

Wallace, J. \& Chen, G., 2005, 'Development and validation of a work-specific measure of cognitive failure: Implications for occupational safety - Wallace - 2005', Journa of Occupational and Organisational Psychology, viewed 26 April 2018, from https://onlinelibrary.wiley.com/doi/abs/10.1348/096317905X37442.

Wang, Y., 2007, 'Forecasting the "Futures" of the evolving police operation: A theoretical note', The Police Journal 80(1), 79-90. https://doi.org/10.1350/ pojo.2007.80.1.79

Weaver, A., Wetterneck, T., Whelan, C. \& Hinami, K., 2015, 'A matter of priorities? Exploring the persistent gender pay gap in hospital medicine', Journal of Hospital Medicine 10(8), 486. https://doi.org/10.1002/jhm.2400

Westover, J. \& Taylor, J., 2010, 'International differences in job satisfaction: The effects of public service motivation, rewards and work relations', International Journal of Productivity and Performance Management 59(8), 811-828. https://doi. org/10.1108/17410401011089481

Wood, V.R., Chonko, L.B. \& Hunt, S.D., 1986, 'Social responsibility and persona success: Are they incompatible', Journal of Business Research 14(3), 193-212. https://doi.org/10.1016/0148-2963(86)90001-9

Wood, V.R. \& West, S.G., 2015, A study of job satisfaction, Sage, Thousand Oaks, CA.

Yip, C., Han, N.L.R. \& Sng, B.L., 2016, 'Legal and ethical issues in research', Indian Journal of Anaesthesia 60(9), 684. https://doi.org/10.4103/0019-5049.190627 